\title{
Differential cellular expression of organic anion transporting peptides OATP1A2 and OATP2B1 in the human retina and brain: implications for carrier-mediated transport of neuropeptides and neurosteriods in the CNS
}

\author{
Gao, Bo ; Vavricka, Stephan R ; Meier, Peter J ; Stieger, Bruno
}

\begin{abstract}
Organic anion transporting polypeptides (OATPs) are polyspecific organic anion transporters, which are expressed in the blood-brain barrier, the choroid plexus, and other organs. The physiologic function of OATPs in extrahepatic tissues remains ambiguous. In rat retina, members of the OATP family are expressed. We therefore investigated the human retina for the expression of OATP1A2 and OATP2B1 and extended the study to human brain. Furthermore, we searched for peptide neurotransmitters as novel OATP substrates. OATP1A2 displayed a broad expression pattern in human retina as assessed by immunofluorescence localization. It is expressed in photoreceptor bodies and somas of amacrine cells. OATP1B2 expression is restricted to the inner nuclear layer and to the inner plexiform layer. Using paraffin sections from human cortex, cerebellum, and hippocampus, OATP1A2 was localized to neurons and neuronal processes, while OATP2B1 is expressed in endothelial cells of brain capillaries. Substance $\mathrm{P}$ and vasoactive intestinal peptide were identified as substrates for OATP1A2 and OATP2B1. Doublelabeling immunofluorescence of human retina demonstrated the presence of substance $\mathrm{P}$ and of vasoactive intestinal peptides in neurons expressing OATP1A2 and OATP2B1, respectively. The expression of OATP1A2 and OATP2B1 in retinal neurons implies a role of these transporters in the reuptake of peptide neurotransmitters released from retinal neurons. The abundant expression of OATP1A2 in brain neurons points to the possibility that OATP1A2 could be involved in the homeostasis of neurosteroids. The high expression of OATP2B1 in brain capillaries supports an important function of OATPs in substance penetration across the blood-brain barrier.
\end{abstract}

DOI: https://doi.org/10.1007/s00424-014-1596-x

Posted at the Zurich Open Repository and Archive, University of Zurich

ZORA URL: https://doi.org/10.5167/uzh-111561

Journal Article

Accepted Version

Originally published at:

Gao, Bo; Vavricka, Stephan R; Meier, Peter J; Stieger, Bruno (2015). Differential cellular expression of organic anion transporting peptides OATP1A2 and OATP2B1 in the human retina and brain: implications for carrier-mediated transport of neuropeptides and neurosteriods in the CNS. Pflügers Archiv : European Journal of Physiology, 467(7):1481-1493.

DOI: https://doi.org/10.1007/s00424-014-1596-x 


\section{Pflügers Archiv - European Journal of Physiology \\ Differential cellular expression of Organic anion transporting peptides OATP1A2 and OATP2B1 in the human retina and brain: Implications for carrier-mediated transport of neuropeptides and neurosteriods in the CNS \\ --Manuscript Draft--}

Manuscript Number:

Full Title:

\begin{tabular}{|l}
\hline Article Type: \\
\hline Corresponding Author: \\
\hline $\begin{array}{l}\text { Corresponding Author Secondary } \\
\text { Information: }\end{array}$ \\
\hline Corresponding Author's Institution: \\
\hline $\begin{array}{l}\text { Corresponding Author's Secondary } \\
\text { Institution: }\end{array}$ \\
\hline
\end{tabular}

First Author:

First Author Secondary Information:

Order of Authors:

\begin{tabular}{|l}
\hline \\
\hline Order of Authors: \\
\hline Order of Authors Secondary Information:
\end{tabular}

Differential cellular expression of Organic anion transporting peptides OATP1A2 and OATP2B1 in the human retina and brain: Implications for carrier-mediated transport of neuropeptides and neurosteriods in the CNS

Original Paper

Bruno Stieger, Ph.D.

University of Zurich Hospital

Zürich, SWITZERLAND

University of Zurich Hospital

\begin{tabular}{|l|l|}
\hline Abstract: & $\begin{array}{l}\text { Organic anion transporting polypeptides (OATP) are polyspecific organic anion } \\
\text { transporters, which are expressed in the blood brain barrier, the choroid plexus and } \\
\text { other organs. The physiologic function of OATPs in extrahepatic tissues remains } \\
\text { ambiguous. In rat retina, members of the OATP family are expressed. We therefore } \\
\text { investigated the human retina for the expression of OATP1A2 and OATP2B1 and } \\
\text { extend the study to human brain. Furthermore, we searched for peptide } \\
\text { neurotransmitters as novel OATP substrates. OATP1A2 displayed a broad expression } \\
\text { pattern in human retina as assessed by immunofluorescence localization in fixed- } \\
\text { frozen section. It is expressed in photoreceptor bodies and somas of amacrine cells. } \\
\text { OATP1B2 expression is restricted to the inner nuclear layer and to the inner plexiform } \\
\text { layer. Using paraffin sections from human cortex, cerebellum and hippocampus, } \\
\text { OATP1A2 was localized to neurons and neuronal processes, while OATP2B1 is } \\
\text { expressed in endothelial cells of brain capillaries. Substance P and vasoactive } \\
\text { intestinal peptide were identified as substrates for OATP1A2 and OATP2B1. Double- } \\
\text { labeling immunofluorescence of human retina demonstrated the presence of } \\
\text { substance P and of vasoactive intestinal peptides in neurons, which express OATP1A2 } \\
\text { and OATP2B1, respectively. Our data suggest first that OATP1A2 and OATP2B1 may } \\
\text { be involved in the reuptake of peptide neurotransmitters release from retinal neurons. } \\
\text { Second, the abundant expression of OATP1A2 in brain neurons points to the } \\
\text { possibility that OATP1A2 could be involved in the homeostasis of neurosteroids. Third, } \\
\text { the high expression of OATP2B1 of in brain capillaries supports an important function } \\
\text { of OATPs in substance penetration across the blood brain barrier. }\end{array}$ \\
\hline $\begin{array}{l}\text { Andreas Reichenbach } \\
\text { reia@medizin.uni-leipzig.de } \\
\text { idnetified by PubMed }\end{array}$ \\
\hline Suggested Reviewers:
\end{tabular}

\section{Bo Gao}

Stephan R. Vavricka, MD

Peter J. Meier, MD

Bruno Stieger, Ph.D.

Organic anion transporting polypeptides (OATPs) are polyspecific organic anion transporters, which are expressed in the blood brain barrier, the choroid plexus and ambiguous. In rat retina, members of the OATP family are expressed. We therefore investigated the human retina for the expression of OATP1A2 and OATP2B1 and end the study to human brain. Furthermore, we searched for peptide pattern in human retina as assessed by immunofluorescence localization in fixedfrozen section. It is expressed in photoreceptor bodies and somas of amacrine cells. layer. Using paraffin sections from human cortex, cerebellum and hippocampus, OATP1A2 was localized to neurons and neuronal processes, while OATP2B1 is expressed in endothelial cells of brain capillaries. Substance $P$ and vasoactive labeling immunofluorescence of human retina demonstrated the presence of substance $P$ and of vasoactive intestinal peptides in neurons, which express OATP1A2 and OATP2B1, respectively. Our data suggest first that OATP1A2 and OATP2B1 may Second, the abundant expression of OATP1A2 in brain neurons points to the possibility that OATP1A2 could be involved in the homeostasis of neurosteroids. Third, the high expression of OATP2B1 of in brain capillaries supports an important function

reia@medizin.uni-leipzig.de

idnetified by PubMed 


\section{Differential cellular expression of Organic anion transporting peptides}

OATP1A2 and OATP2B1 in the human retina and brain: Implications

for carrier-mediated transport of neuropeptides and neurosteriods in the CNS

Bo Gao ${ }^{1}$, Stephan R. Varvicka ${ }^{1,2}$, Peter J. Meier ${ }^{1,3}$, Bruno Stieger ${ }^{1}$

${ }^{1}$ Department of Clinical Pharmacology and Toxicology, University Hospital, Zurich, Switzerland, ${ }^{2}$ Division of Gastroenterology, University Hospital, Zurich, Switzerland, and ${ }^{3}$ University of Basel, Basel, Switzerland

Corresponding author:

Bruno Stieger, $\mathrm{PhD}$

University Hospital

Department of Clinical Pharmacology and Toxicology

8091 Zurich

Switzerland

Phone: +41-44-255-2068

Fax: $\quad+41-44-255-4411$

Email: Bruno.stieger@uzh.ch 


\begin{abstract}
Organic anion transporting polypeptides (OATPs) are polyspecific organic anion transporters, which are expressed in the blood brain barrier, the choroid plexus and other organs. The physiologic function of OATPs in extrahepatic tissues remains ambiguous. In rat retina, members of the OATP family are expressed. We therefore investigated the human retina for the expression of OATP1A2 and OATP2B1 and extend the study to human brain. Furthermore, we searched for peptide neurotransmitters as novel OATP substrates. OATP1A2 displayed a broad expression pattern in human retina as assessed by immunofluorescence localization in fixed-frozen section. It is expressed in photoreceptor bodies and somas of amacrine cells. OATP1B2 expression is restricted to the inner nuclear layer and to the inner plexiform layer. Using paraffin sections from human cortex, cerebellum and hippocampus, OATP1A2 was localized to neurons and neuronal processes, while OATP2B1 is expressed in endothelial cells of brain capillaries. Substance P and vasoactive intestinal peptide were identified as substrates for OATP1A2 and OATP2B1. Double-labeling immunofluorescence of human retina demonstrated the presence of substance $\mathrm{P}$ and of vasoactive intestinal peptides in neurons, which express OATP1A2 and OATP2B1, respectively. Our data suggest first that OATP1A2 and OATP2B1 may be involved in the reuptake of peptide neurotransmitters release from retinal neurons. Second, the abundant expression of OATP1A2 in brain neurons points to the possibility that OATP1A2 could be involved in the homeostasis of neurosteroids. Third, the high expression of OATP2B1 of in brain capillaries supports an important function of OATPs in substance penetration across the blood brain barrier.
\end{abstract}




\section{Key Words}

Organic anion transporting polypeptide, neuropeptide, transport, retina, brain 


\section{Introduction}

Organic anion transporting polypeptides (humans OATPs, rodents rOATPs), represent an important group of transporters with a wide spectrum of amphipathic substrates [17, 27]. Initially, OATPs were isolated from liver and localized to the basolateral membrane of hepatocytes, where they mediate sodium-independent transport of bile salts and cholephilic anionic compounds. To date dozens of family members, including 16 in rat, 15 in mouse and 11 in human, have been identified. They are expressed in many organs including kidney, placenta, brain and retina [16, 18, 27]. Besides bile salts, they transport a wide range of endogenous and exogenous compounds, such as steroid hormones and their conjugates, thyroid hormones, prostaglandins, small peptides and numerous drugs. [16, 18] Yet, physiological functions of these transporters in extrahepatic organs remain ambiguous. Since many members are expressed in cells that constitute barriers limiting the exchange of solutes between compartments, e.g. blood brain barrier, choroid plexus epithelium and testis, it is believed that OATPs play a role in maintaining tissue homeostasis, bioavailability and disposition of numerous drugs [16, $25,56]$.

In rat retina, Oatp1a4 and Oatp1a5 have been identified. Oatp1a4 has been localized in the apical region of the retinal pigment epithelium (RPE) [9] and Oatp1a5 in the ganglion and inner nuclear cell layers [24]. Although their distinct functions in the retina remain to be established, evidence that Oatp1a4-mediated transport activities could be competitively inhibited by the N-retinyl-N-retinylidene ethanolamine, an unusual retinoid implicated in the age-related visual impairment [53], suggests that this transporter is involved in accumulating this harmful retinoid in the RPE [9]. Despite their 
potential significance in retinal pathogenesis, it is so far not clear whether OATPs are expressed in human retina.

Therefore, we aimed to investigate the expression of OATPs in human retina. We analyzed OATP1A2 and OATP2B1 in the present study, as they are very likely expressed in the retina for several reasons. First, OATP1A2 is classified with Oatp1a4 and Oatp1a5 in Oatp1a/OATP1A subfamily [17] and thus closely related to the rat Oatps expressed in the retina. Second, these two OATPs are abundantly expressed in the brain $[29,30]$. It is well known that many brain-expressed neurotransmitter transporters are also expressed in retina [3]. Finally, OATP1A2 and OATP2B1 display strong expression in the ocular ciliary body epithelium [8], a tissue with which retina is anatomically connected and has a common embryonic origin. Previously, we have reported the expression of OATP1A2 in brain capillary endothelium [7], but the cellular localization of OATP2B1 was not determined. Given the expression of neurotransmitter transporters in retina and in brain, we included human brain into the localization studies. Finally, we searched for physiologic substrates pertinent to the cell type specific expression of OATP1A2 and OATP2B1. 


\section{Materials and Methods}

Antibodies

Polyclonal affinity purified OATP1A2 and OATP2B1 were generated in rabbits and characterized as previously described $[7,8,22,30]$ Guinea pig anti-substance P (SP) and sheep anti-vasoactive intestinal peptide (VIP) were purchased from Chemicon (Temecula, CA, USA). All secondary antibodies conjugated with either $\mathrm{Cy} 2$ or $\mathrm{Cy} 3$ fluorochrome and with biotin-horseradish peroxidase were purchased from Jackson Immunoresearch (West Grove, PA, USA) and Santa Cruz (Santa Cruz, CA, USA), respectively.

\section{Chemicals}

${ }^{3}$ H-labeled SP was purchased from PerkinElmer Life Sciences, Inc (Boston, MA, USA), and ${ }^{125}$ I-labeled somatostatin, VIP and neuropeptide Y (NPY) were from Amersham Bioscience (Buckinghamshire, England). Unlabeled SP and VIP were from Bachem (Basel, Switzerland). All other chemicals were obtained from Fluka (Buchs, Switzerland), Merck (Whitehouse Station, NJ, USA) and Sigma Chemicals (St. Louis, MO, USA) at the highest purity available.

Human tissue collections

Retinas were collected from four deceased patients of both genders (age range: 25-88 years) during routine autopsies (post-mortem periods: $8-12$ hours) in the Department of Ophthalmology, University Hospital Zurich, according to a protocol approved by the local Ethics Committee. One of these retinas was used for immunoblot analysis, thus frozen immediately in liquid nitrogen upon dissection. The other retinas were fixed as described below for immunofluorescence staining experiments. Human 5 
$\mu \mathrm{m}$ brain sections embedded in paraffin were provided by the Department of Neuropathology, University Hospital Zürich. They were cut from the frontal cerebral cortex and the hippocampal formation. These specimens were from two patients (both genders, aged 39- and 79-year-old) without evidence of neurological or psychiatric disorders and with normal brain morphology. The post-mortem intervals were $30-48$ hours. The blocks of the specimens were fixed routinely with formalin after removal during autopsy.

Immunoblot analysis

The isolated human retina was processed as described in[9]. In brief, it was homogenized in $100 \mathrm{mM}$ Tris $\mathrm{pH} 7.5$ with a tip sonicator and the homogenates were centrifuged at $1000 \mathrm{x} \mathrm{g}$ for 5 minutes to remove large debris. Protein content of the supernatant was assessed by the Bradford assay (BioRad, Hercules, CA) using BSA as standard. The supernatant was mixed with SDS sample buffer, heated to $70^{\circ} \mathrm{C}$ for 10 minutes and stored at $-20^{\circ}$ until use. Proteins were separated on $7.5 \%$ SDSpolyacrylamide gels and transferred to nitrocellulose membranes. Blots were blocked for $1 \mathrm{hr}$ at room temperature in $10 \mathrm{mM}$ Tris/ $\mathrm{HCl}(\mathrm{pH} \mathrm{8.0)}, 150 \mathrm{mM} \mathrm{NaCl}$, and $0.05 \%(\mathrm{w} / \mathrm{v})$ Tween (TBST) containing $5 \%(w / v)$ blocker (nonfat dry milk, Bio-Rad) and incubated overnight at $4{ }^{\circ} \mathrm{C}$ with primary antibodies in TBST containing $5 \%(\mathrm{w} / \mathrm{v})$ blocker. After rinsing, blots were incubated with horseradish peroxidase-conjugated goat anti-rabbit IgG diluted at 1:5000 for $1 \mathrm{hr}$ at room temperature and immunoreactivity was visualized with the Renaissance Western blot detection kit (NEN Life Science products, Boston, MA, USA).

Immunofluorescence staining 
Dissected retinas were fixed in phosphate-buffered saline (PBS) containing 3\% (w/v) paraformaldehyde and $0.1 \%(\mathrm{w} / \mathrm{v})$ glutaraldehyde $(\mathrm{pH} 7.4)$ at $4^{\circ} \mathrm{C}$ for 2 hours, cryoprotected in $30 \%(\mathrm{w} / \mathrm{v})$ sucrose overnight at $4^{\circ} \mathrm{C}$, embedded in M1-embedding matrix (Lipshaw, Pittsburg, PA, USA) and stored at $-70^{\circ} \mathrm{C}$ until use.

$10 \mu \mathrm{m}$ vertical cryostat sections were cut and mounted on glass slides coated with $0.5 \%$ gelatin and incubated with primary antibodies in phosphate saline buffer (PBS) containing $2 \%(\mathrm{v} / \mathrm{v})$ normal goat serum and $0.2 \%(\mathrm{w} / \mathrm{v})$ Triton X-100 overnight at $4^{\circ} \mathrm{C}$. The dilution for OATP1A2 was $3 \mu \mathrm{g} / \mathrm{ml}$ and for OATP2B1 $1 \mu \mathrm{g} / \mathrm{ml}$. Sections were washed three times with PBS and incubated for 30 minutes at room temperature with the Cy3conjugated goat anti-rabbit antibody (1:300) diluted in the same buffer as for the primary antibody incubation. Subsequently sections were washed several times with PBS and coverslipped with Immu-mount (Shandon, Pittsburgh, PA, USA). For double staining experiments, sections were coincubated one of the OATP antibodies with either anti-SP or anti-VIP. The signal for OATP1A2 and OATP2B1 was detected with the Cy3conjugated goat anti-rabbit antibody (1:300), and for SP and VIP was with a Cy2conjugated goat antibody against corresponding species.

Immunoperoxidase staining

Because of the very high level of autofluorescence on human brain sections, immunoperoxidase staining was used to detect signals in the brain specimens. The sections were first dewaxed with xylone and hydrated by passing through descending serial ethanol solutions, then treated with $0.1 \mathrm{M}$ hydrochloride acid for $10 \mathrm{~min}, 0.1 \%$ (w/v) saponin in PBS for 30 min and finally with $1.5 \%(w / v)$ hydrogen peroxide for 10 min to eliminate endogenous peroxidase activivity. For antigen-retrieval, sections were 
immersed in $0.2 \mathrm{M}$ citric acid $(\mathrm{pH} 4.5)$ and heated 3 times to $80^{\circ} \mathrm{C}$ for $5 \mathrm{~min}$ in a microwave processor. In initial experiments sections were heated for 1, 3 and 5 times in order to optimize detection, and 3 times of microwave radiation was found suitable for the present study. Afterwards sections were incubated overnight at $4^{\circ} \mathrm{C}$ with antibodies to OATP1A2 $(10 \mu \mathrm{g} / \mathrm{ml})$ or OATP2B1 $(3 \mu \mathrm{g} / \mathrm{ml})$ diluted in $50 \mathrm{mM}$ Tris/100 mM NaCl (Trissaline, $\mathrm{pH} 7.4)$ containing $2 \%(\mathrm{w} / \mathrm{v})$ normal goat serum and $0.05 \%(\mathrm{w} / \mathrm{v})$ Triton $\mathrm{X}-100$. They were washed in Tris-saline and stained by the ABC-immunoperoxidase method with Vectastain Elite kit (Vector Laboratories, Burlingame, CA, USA) and diaminobenzidine hydrochloride as chromogen. Finally, sections were dehydrated with ascending series of ethanol, and coversplipped out of xylene. Negative control experiments in which sections were incubated with the primary antibody preabsorbed with $5-10 \mathrm{mg} / \mathrm{ml}$ of corresponding peptides used for immunization were carried out to verify the specificity of the positive signal. After processing. sections were analyzed by confocal laser microscopy (MRC 600 confocal imaging system, BioRad Laboratories, Richmont, CA) using a Zeiss Axioplan microscope (Oberkochen, Germany).

Transport assays in Xenopus laevis oocytes

Mature $X$. laevis females were purchased from the African Xenopus facility (Noordhoek, Republic of South Africa) and kept under standard conditions. The animals received human care according to federal and local regulations and the experiments were approved by the local government's animal care committee. In vitro synthesis of cRNAs for OATP1A2 and OATP2B1 was performed from the respective cDNAs as described $[29,30]$. 
Oocytes were prepared and as previously described [44]. Healthy oocytes were microinjected with either water (control) or 5ng of cRNA encoding OATP1A2 or OATP2B1. The oocytes were cultured for three days to allow expression of the transporter proteins. Tracer uptake experiments were carried out in the presence of $\mathrm{Na}^{+}$ $(100 \mathrm{mM} \mathrm{NaCl})$ or absence of $\mathrm{Na}^{+}(100 \mathrm{mM}$ choline chloride) in uptake media containing $2 \mathrm{mM} \mathrm{KCl}, 1 \mathrm{mM} \mathrm{CaCl} 2,1 \mathrm{mM} \mathrm{MgCl}_{2}$, and $10 \mathrm{mM} \mathrm{HEPES} /$ Tris (pH 7.5). Fifteen oocytes were prewashed in the uptake medium and then incubated at $25{ }^{\circ} \mathrm{C}$ in $100 \mu 1$ of uptake medium supplemented with radiolabeled and unlabeled compounds. Subsequently, oocytes were washed 3 times with $6 \mathrm{ml}$ of ice-cold incubation buffer without radiolabelled substrate and single oocytes were dissolved in $10 \%$ SDS. After addition of $5 \mathrm{ml}$ of scintillation fluid (Ultima Gold; Canberra Industries, Meriden, CT), the oocyte-associated radioactivity was measured in a Packard Tri-Carb 2200 CA liquid scintillation analyzer (Canberra Industries). Statistical significance was calculated with the unpaired Student's $t$-test (Systat, SPSS, Chicago IL). Km values were estimated by non-linear regression analysis using the Michaelis-Menten model with Systat. Uptake values into transporter expressing oocytes were corrected for uptake into water injected oocytes. 


\section{Results}

Expression of the OATP1A2- and OATP2B1-immunoreactivity in the human retina

Immunofluorescence microscopy analysis of retina sections demonstrated that both antibodies displayed strongly reactivity (Fig 1A and 2A). Surprisingly however, no immunoreactivity was observed in the apical region of the retina pigment epithelium, the site at which Oatp1a4 immunoreactivity is located in rat retina [9]. OATP1A2 immunoreactivity appeared broadly in many retina cell layers, including the outer nuclear layer (ONL), inner nuclear layer (INL), inner plexiform layer (IPL) and the ganglion cell layer (GCL) (Fig 1A). At high magnification, the staining in the ONL was seen at the plasma membrane of photoreceptor bodies (Fig. 1C). In the INL, OATP1A2 immunjoreactivity was abundant in many cell somas that are lying in the innermost part of the layer, resembling amacrine neurons. These cells were often seen to extend their strongly stained processes into the IPL and GCL (Fig. 1 E). In the GCL, a few small cells were also stained, whereas large ganglion cells appeared negative (Fig. 1E and Fig 6A). For OATP2B1, the staining was rather restricted to the innermost part of the INL and in the IPL (Fig. 2A). At high magnification, the OATP2B1-IR in the INL was present in proximal processes of amacrine cells, but sparsely in their somas (Fig. 2C, Fig. 6B and Fig. 7B). In the IPL, numerous neuronal processes were stained, forming a dense plexus of OATP2B1 immunoreactivity throughout the entire layer (Fig. 2A and 2C).

In control experiments in which adjacent sections were incubated with antibodies preabsorbed with the corresponding peptide antigens used for immunization, no positive 
signals were detected (Fig. 1B and 2B), whereby the faint reaction in the RPE is due to autofluorescence of the tissue.

Western blot experiments were carried out to further confirm the presence of OATP1A2 and OATP2B1 proteins in the retina. As illustrated in Fig. 3, both antibodies reacted specifically with retina homogenates. OATP1A2 and OATP2B1 proteins in the retina appear to have a similar size $(\sim 70-80 \mathrm{kDa})$ to that identified in the liver, placenta, and ciliary body $[8,30,48]$.

OATP1A2- and OATP2B1-mediated transport activities of bioactive peptides in Xenopus laevis oocytes

The findings that OATP1A2 and OATP2B1 are present in the retina amacrine neurons prompted us to assume that these transporters may play a role in mediating transport of some neuronal messengers, such as neurotransmitters or neuroactive peptides. While previous data have indicated that neurotransmitters, such as GABA, glutamine and serotonin, are most likely not substrates of rat Oatps [40], it is not clear, however, whether this assumption also holds true for human OATPs. Human amacrine neurons are known for containing several neurotransmitters such as GABA, dopamine, glycine and glutamate [5, 43], and many bioactive peptides, including SP, VIP, somatostatin (SOM) and NPY [6, 33, 39, 49, 54]. To corroborate our hypothesis that OATP1A2 and OATP2B1 may mediate transport of some of the neuroactive substances, functional transport assays were performed in OATP-expressing oocytes. Not surprisingly, no transport activities were found for neurotransmitters GABA, glutamate, glycine and dopamine (not shown) in these experiments. However, compared with waterinjected oocytes OATP1A2- and OATP2B1-expressing oocytes exhibited 2-3 fold uptake 
signals for SP and VIP, but not for SOM and NPY (Fig. 4). Further analysis indicated that OATP1A2- and OATP2B1-mediated uptake for SP and VIP was sodiumindependent (Fig. 4A and B) and saturable with apparent Km-values of $76 \mu \mathrm{M}$ and 73 $\mu \mathrm{M}$ for OATP1A2-mediated SP and VIP uptake and $84 \mu \mathrm{M}$ and $94 \mu \mathrm{M}$ for OATP2B1mediated SP and VIP uptake, respectively (Fig. 5).

Expression of the OATP1A2- and OATP2B1-IR in retina SP- and VIP-containing neurons

It is well known that neurotransmitter transporters are often expressed in the same neurons that release corresponding neurotransmitters in order to take up again released neurotransmitters back into neurons. Since OATP1A2 and OATP2B1 exhibit transport activities for SP and VIP, we investigated whether OATP1A2 and OATP2B1 are expressed in subpopulations of amacrine cells that contain SP and VIP [6, 33, 54]. Double fluorescence staining experiments with antibodies against OATPs and against SP and VIP showed extensive colocalization of OATP1A2 immunoreactivity with SP labelling, both in amacrine cell somas in the INL and in neurites of the IPL and GCL (Fig. 6A). A few SP-containing cells in GCL, previously identified as SP-containing amacrine cells $[2,19,60]$, were also labeled with OATP1A2 (Fig. 6A). OATP1A2 immunoreactivity was also colocalized with VIP fluorescence, particularly in the small cells and neurites in the GCL, but less in the IPL and INL (Fig.7A). OATP2B1 immunoreactivity was, although to a lesser extent, also colocalized with SP labeling, especially at neuronal processes in the IPL (Fig. 6B). When the OATP2B1 antibody was coincubated with the VIP antibody, the OATP2B1 immunoreactive neuronal processes were intensely colocalized with VIP fluorescence (Fig. 7B). 
In addition, to clarify whether the abundant OATP immunoreactivity in the GCL (Fig. 1A) is also present in retinal macroglial cells (astrocytes and Müller cells) localized in this layer [58], double staining experiments were performed in which the antiOATP1A2 antibody was coincubated with an anti-glial fibrillary acidic protein, a glial marker. No colocalization of the OATP1A2-IR with the glia cell marker was found in these experiments (not shown).

Localization of OATP1A2 and OATP2B1 in the human frontal cortex and hippocampus

Expression of OATP1A2 and OATP2B1 in the retina neurons raises the possibility that the two OATPs may be also expressed in brain neurons. We have previously detected a weak, but distinct expression of the OATP1A2 immunoreactivity in brain capillary endothelial cells on fresh cryostat sections of the cerebral cortex [7], while on Northern blots OATP1A2 is abundantly expressed in human brain [29]. Mildly fixed cryostat sections, although perhaps good for detection of some antigens, usually have poorly preserved the plasma membrane structure, thus may not be very suitable for recognizing proteins associated neuronal processes. In the present study we used paraffin embedded sections and applied a microwave antigen-retrieval protocol. With this protocol OATP1A2 was found to be abundantly expressed in neurons in both, cortex and hippocampus (Fig. 8 and 9). As illustrated in Fig. 8A, in the frontal cortex neurons scattered all layers were labeled with the OATP1A2 immunoreactivity. In the hippocampal formation, shown in Fig. 9, pyramidal neurons in the CA1 and CA2 region and granule cells in the dentate gyrus were also strongly labeled. Under high magnification, the OATP1A2 immunoreactivity was associated with the plasma 
membrane of cell somas and with neuronal processes (Fig. 8C, 9B and C). Consistent with the previous finding [7], OATP1A2 immunoreactivity was also occasionally found in capillary endothelial cells (Fig. 8A and C) in the paraffin sections used for this study.

Surprisingly though, the OATP2B1 immunoreactivity was distinctly associated with brain capillary endothelial cells (Fig. 10) in both brain regions examined. The staining was clearly associated with the plasma membrane of the endothelium under high magnification (Fig. 10C). OATP2B1 immunoreactivity associated endothelial cells were numerous in both the cortex and hippocampus. The abundant expression of OATP2B1 in capillary endothelial cells suggests that this transporter plays an important role at the BBB. 


\section{Discussion}

The data presented here show: (1) OATP1A21 and OATP2B1 are abundantly expressed in retina SP- and VIP- containing amacrine neurons and their processes; (2) OATP1A2 and OATP2B1 exhibit transport activities for SP and VIP when expressed in X. laevis oocytes; (3) in the cerebral cortex and hippocampal formation OATP1A2 is predominantly present in various types of neurons and OATP2B1 exclusively in the blood-brain barrier.

The diversity of cellular distribution of OATP1A2 and OATP2B2 in the CNS is somewhat surprising. This diversity is reflected not only in different cell types, but also in various types of neurons with distinct neurotransmitter phenotypes. For example, OATP2B1 in retina is distinctly present in amacrine neurons (Fig. 2), whereas in the brain it localizes to the capillary endothelium (Fig. 10). OATP1A2 is expressed in amacrine cells (Fig. 1) that contain inhibitory neurotransmitters, e.g. GABA [5], and also in neurons containing the excitatory neurotransmitter glutamate, such as photoreceptor cells, hippocampal pyramidal and granule cells $[1,5]$. It was previously noted in rat that the retina utilizes different mechanisms from the brain for regulating the expression of transporters. For example, the glycin transporter Glyt1 is expressed in glia cells of rat brain and in amacrine cells in the retina [59]. In humans, Glyt-1 expression is absent in Müller cells of intact retina, but present in cultured Müller cells [45]. Similarly, while the glutamate transporter GLT-1 is located in brain in glial cells, it is found neurons of the retina [52]. So far, the knowledge about factors involved in determining the differential cellular expression of such transporters is still in its infancy [10, 45]. Our findings of the OATP2B1 localization to distinct cells in brain and retina are another example of 
differential regulation of transporter expression in the CNS [45] The highly heterogeneous cellular distribution and their multispecific transport properties [16] indicate complex functions of OATP1A2 and OATP2B1 in the CNS.

In the present study we have identified the neuropeptides SP (11 amino acids) and VIP (28 amino acids) as substrates of OATP1A2 and OATP2B1. This result is not unexpected since Oatps/OATPs seem to have preferences for small peptides with 10-20 amino acids [16]. Our data, however, do not definitively proof that OATPs function as peptide uptake systems in the CNS as do they do for example in liver [23] or across BBB [7]. Neuropeptides, stored in synaptic vesicles, are often released together with neurotransmitters by presynaptic neurons. Unlike neurotransmitters that are mostly recycled back to neurons by their corresponding transporters, elimination of neuroactive peptides from the synaptic cleft is generally thought by diffusion and, more importantly, by degradation with peptidases. Of several enzymes that are involved in metabolizing SP and VIP [4, 21, 36], neutral endopeptidase (NEP, EC. 3.4.24.11) appears to play a predominant role in the brain $[11,12,20,21,38,55]$. This enzyme is abundantly present in the striatonigral pathway but scarcely, if at all, in the cerebral cortex (100\% vs. $4 \%)$ [38]. Thus, NEP distribution seems to be only matched, notably in striatonigral pathway, with that of SP, but not in the cerebral cortex where both SP- and VIP- containing neurons and their processes are abundantly located [34, 35]. This only partially matched distribution pattern was also demonstrated in a detailed immunohistochemistry analysis [37]. There is no report so far, to our knowledge, on the presence of NPE in the retina. Another peptidase angiotensin-converting enzyme (3.4.15.1) is also suggested to be involved in inactivation of SP in the brain $[21,51]$. It has a very low capacity compared 
to that of NEP [21], and is also mainly present in the striatonigral pathway [51]. In the retina angiotensin converting enzyme was only detected in chicken after pretreatment with protease inhibitors [57], but not in the rat [50], suggesting a at best a low expression level in this tissue. Taken together, the partially matched distribution pattern raises a possibility that alternative mechanism(s) may be involved in determining turning over the released neuroactive peptides in the synaptic cleft, particularly in areas that are short of degrading enzymes but rich in peptides, such as the cerebral cortex [34, 35, 47] and retina. Our findings that OATP1A2 and OAPT2B1 are abundantly present in the cerebral cortex and retina, and that they exhibit saturable transport activity for SP and VIP argue for a functional role of these OATPs in clearing released neuropeptides. Their rather low affinities $(\mathrm{Km} \sim 70-100 \mu \mathrm{M})$ for these peptides appear to be in agreement with the generally prolonged actions of neuroactive peptides. Moreover, expression of these transporters in peptide-containing neurons (Fig. 6 and 7) suggests that these transporters may reuptake these neuroactive peptides back to the neurons as do neurotransmitter transporters. In this context, it is interesting to note that the amacrine cell of retina is a special type of nerve cells lacking an axon but their dendrites functioning as "axon-like" processes. Extensive expression of OATP1A2 and OATP2B1 in peptide-containing processes in the IPL (Fig. 6 and 7) thus suggests that uptake activity, at least in the retina, may occur at peptide-releasing sites.

OATP1A2 and OATP2B1 may also mediate transport of other neuroactive substances in the CNS, as suggested by their broad substrate specificity and diverse cellular expression pattern. Of these, neurosteriods and their sulfate conjugates are of particular interest. OATP1A2 exhibits a very high transport activity for 
dehydroepiandrosterone sulfate (DHEAS, $\mathrm{Km} \sim 6 \mu \mathrm{M}$ ) and estrone-3-sulfate (E3S) [28, 30]. For OATP2B1 these two steroids, together with pregneneolone sulfate (PREGS) [13], are essentially the only natural substrates identified so far [16]. Functionally, steroid hormones are originally thought to regulate by binding to intracellular steroid receptors gene expression and translational processes within cells and hence exerting genomic effects. Substantial evidence has also accumulated indicating that some steroids, such as pregenolone, dehydroepianderosterone, 17- $\beta$-estradiol (both unsulfated and sulfated forms), can modulate neurotransmission by acting directly on neurotransmitter receptors such as NMDA and GABA receptors on the cell surface, thus functioning as an important group of neuromessengers and hence exert non-genomic effects [46]. It was believed that brain steroids were only supplied by blood circulation from the peripheral organs such as adrenal glands and gonads. Several studies have recently demonstrated that the machinery for synthesizing these neuroactive stereroids and their sulfate esters is present in brain and retina $[14,15,31]$. Pyramidal and granule neurons in the hippocampal formation [26] and ganglion neurons in the retina [14] appear to be the primary synthesizing sites in the two tissues. Thus, abundant expression of OATP1A2 on the surface of these cells (Fig 1 and 9), together with its transport activity for neurosteroids, is very intriguing. It is not clear how neurons release neurosteroids produced at the endoplasmic reticulum and mitochodria and how they are eliminated from the synaptic cleft $[41,42]$. According to a current model, newly synthesized neuroactive steroids present in the cytosol diffuse slowly across the plasma membrane to reach target receptors or may diffuse within the membrane laterally to their target [41]. These proposed mechanisms are very different from neurotransmitters and neuroactive 
neuropeptides that are packed into synaptic vesicles and released via exocytosis upon presynaptic membrane excitation. Although it is not known whether (a) transport system(s) is involved in this process one can assume that OATP1A2, resided at the plasma membrane of the hippocampal pyramidal and granule cells and exhibiting high transport activities for the neuroactive steroids, may facilitate transport of these amphipathic substances across the plasma membrane. OATP2B1, localized on the nearby capillary endothelial cells (Fig. 10), on the other hand, may transport these steroids out of releasing sites. Moreover, since Oatps/OATPs-mediated transport appear to be bidirectional [32], OATP2A1 may also play a role in reuptake of these substances back to the cell and OATP2B1 in delivering blood-borne steroids to target sites.

In conclusion, our data suggest thatOATP1A2 and OATP2B1 are involved in mediating transport of neuropeptides and neurosteroids across the plasma membrane of neurons and capillary endothelium. Further characterization of these transporters in vivo is essential to clarify the data from the present study. Furthermore, the significance of these OATPs in mediating transport of other endogenous substances including prostaglandins, and in bioavailability and disposition of drugs in the CNS need to be explored in future. 


\section{Acknowledgements}

BS is supported by grant \# 310030_144195 / 1 from the Swiss National Science foundation. The authors thank Hanspeter Iseli and Charlotte Remé for providing the human specimens. 


\section{References}

1. Brandon C, Lam DM (1983) L-glutamic acid: a neurotransmitter candidate for cone photoreceptors in human and rat retinas. Proc Natl Acad Sci U S A 80:5117-21 DOI

2. Brecha NC, Sternini C, Anderson K, Krause JE (1989) Expression and cellular localization of substance P/neurokinin A and neurokinin B mRNAs in the rat retina. Vis Neurosci 3:527-35

3. Bringmann A, Pannicke T, Biedermann B, Francke M, Iandiev I, Grosche J, Wiedemann P, Albrecht J, Reichenbach A (2009) Role of retinal glial cells in neurotransmitter uptake and metabolism. Neurochem Int 54:143-60 DOI S01970186(08)00202-7 [pii] 10.1016/j.neuint.2008.10.014

4. Caughey GH, Leidig F, Viro NF, Nadel JA (1988) Substance P and vasoactive intestinal peptide degradation by mast cell tryptase and chymase. J Pharmacol Exp Ther 244:133-7

5. Crooks J, Kolb H (1992) Localization of GABA, glycine, glutamate and tyrosine hydroxylase in the human retina. J Comp Neurol 315:287-302 DOI $10.1002 /$ cne. 903150305

6. Cuenca N, De Juan J, Kolb H (1995) Substance P-immunoreactive neurons in the human retina. J Comp Neurol 356:491-504 DOI 10.1002/cne.903560402

7. Gao B, Hagenbuch B, Kullak-Ublick GA, Benke D, Aguzzi A, Meier PJ (2000) Organic anion-transporting polypeptides mediate transport of opioid peptides across blood-brain barrier. J Pharmacol Exp Ther 294:73-9 
8. Gao B, Huber RD, Wenzel A, Vavricka SR, Ismair MG, Reme C, Meier PJ (2005) Localization of organic anion transporting polypeptides in the rat and human ciliary body epithelium. Exp Eye Res 80:61-72

9. Gao B, Wenzel A, Grimm C, Vavricka SR, Benke D, Meier PJ, Reme CE (2002) Localization of organic anion transport protein 2 in the apical region of rat retinal pigment epithelium. Invest Ophthalmol Vis Sci 43:510-4

10. Gegelashvili G, Robinson MB, Trotti D, Rauen T (2001) Regulation of glutamate transporters in health and disease. Prog Brain Res 132:267-86 DOI S00796123(01)32082-4 [pii] 10.1016/S0079-6123(01)32082-4

11. Goetzl EJ, Sreedharan SP, Turck CW, Bridenbaugh R, Malfroy B (1989) Preferential cleavage of amino- and carboxyl-terminal oligopeptides from vasoactive intestinal polypeptide by human recombinant enkephalinase (neutral endopeptidase, EC 3.4.24.11). Biochem Biophys Res Commun 158:850-4 DOI 0006-291X(89)92800-3 [pii]

12. Groneberg DA, Rabe KF, Fischer A (2006) Novel concepts of neuropeptide-based drug therapy: vasoactive intestinal polypeptide and its receptors. Eur J Pharmacol 533:182-94 DOI S0014-2999(05)01385-3 [pii] 10.1016/j.ejphar.2005.12.055

13. Grube M, Kock K, Karner S, Reuther S, Ritter CA, Jedlitschky G, Kroemer HK (2006) Modification of OATP2B1-mediated transport by steroid hormones. Mol Pharmacol 70:1735-41

14. Guarneri P, Guarneri R, Cascio C, Pavasant P, Piccoli F, Papadopoulos V (1994) Neurosteroidogenesis in rat retinas. J Neurochem 63:86-96 
15. Gunn BG, Brown AR, Lambert JJ, Belelli D (2011) Neurosteroids and GABA(A) Receptor Interactions: A Focus on Stress. Front Neurosci 5:131 DOI 10.3389/fnins.2011.00131

16. Hagenbuch B, Gui C (2008) Xenobiotic transporters of the human organic anion transporting polypeptides (OATP) family. Xenobiotica 38:778-801 DOI 795433551 [pii] $10.1080 / 00498250801986951$

17. Hagenbuch B, Meier PJ (2004) Organic anion transporting polypeptides of the OATP/SLC21 family: Phylogenetic classification as OATP/SLCO superfamily, new nomenclature and molecular/functional properties. Pflugers Arch 447:653-665

18. Hagenbuch B, Stieger B (2013) The SLCO (former SLC21) superfamily of transporters. Mol Aspects Med 34:396-412 DOI 10.1016/j.mam.2012.10.009 S00982997(12)00123-9 [pii]

19. Hannibal J, Fahrenkrug J (2002) Immunoreactive substance P is not part of the retinohypothalamic tract in the rat. Cell Tissue Res 309:293-9 DOI 10.1007/s00441-0020564-5

20. Harrison S, Geppetti P (2001) Substance p. Int J Biochem Cell Biol 33:555-76 DOI S1357-2725(01)00031-0 [pii]

21. Hooper NM, Turner AJ (1987) Isolation of two differentially glycosylated forms of peptidyl-dipeptidase A (angiotensin converting enzyme) from pig brain: a re-evaluation of their role in neuropeptide metabolism. Biochem J 241:625-33

22. Huber RD, Gao B, Sidler Pfandler MA, Zhang-Fu W, Leuthold S, Hagenbuch B, Folkers G, Meier PJ, Stieger B (2007) Characterization of two splice variants of human 
organic anion transporting polypeptide $3 \mathrm{~A} 1$ isolated from human brain. Am J Physiol Cell Physiol 292:C795-806

23. Ismair MG, Stieger B, Cattori V, Hagenbuch B, Fried M, Meier PJ, Kullak-Ublick GA (2001) Hepatic uptake of cholecystokinin octapeptide by organic anion-transporting polypeptides OATP4 and OATP8 of rat and human liver. Gastroenterology 121:1185-90

24. Ito A, Yamaguchi K, Onogawa T, Unno M, Suzuki T, Nishio T, Sasano H, Abe T, Tamai M (2002) Distribution of organic anion-transporting polypeptide 2 (oatp2) and oatp3 in the rat retina. Invest Ophthalmol Vis Sci 43:858-63

25. Iusuf D, van de Steeg E, Schinkel AH (2012) Functions of OATP1A and 1B transporters in vivo: insights from mouse models. Trends Pharmacol Sci 33:100-8 DOI 10.1016/j.tips.2011.10.005

26. Kimoto T, Tsurugizawa T, Ohta Y, Makino J, Tamura H, Hojo Y, Takata N, Kawato S (2001) Neurosteroid synthesis by cytochrome p450-containing systems localized in the rat brain hippocampal neurons: N-methyl-D-aspartate and calcium-dependent synthesis. Endocrinology 142:3578-89

27. Konig J, Seithel A, Gradhand U, Fromm MF (2006) Pharmacogenomics of human OATP transporters. Naunyn Schmiedebergs Arch Pharmacol 372:432-43

28. Kullak-Ublick GA, Fisch T, Oswald M, Hagenbuch B, Meier PJ, Beuers U, Paumgartner G (1998) Dehydroepiandrosterone sulfate (DHEAS): identification of a carrier protein in human liver and brain. FEBS Lett 424:173-6

29. Kullak-Ublick GA, Hagenbuch B, Stieger B, Schteingart CD, Hofmann AF, Wolkoff AW, Meier PJ (1995) Molecular and functional characterization of an organic anion transporting polypeptide cloned from human liver. Gastroenterology 109:1274-82 
30. Kullak-Ublick GA, Ismair MG, Stieger B, Landmann L, Huber R, Pizzagalli F, Fattinger K, Meier PJ, Hagenbuch B (2001) Organic anion-transporting polypeptide B (OATP-B) and its functional comparison with three other OATPs of human liver. Gastroenterology 120:525-33

31. Le Goascogne C, Robel P, Gouezou M, Sananes N, Baulieu EE, Waterman M (1987) Neurosteroids: cytochrome P-450scc in rat brain. Science 237:1212-5

32. Leuthold S, Hagenbuch B, Mohebbi N, Wagner CA, Meier PJ, Stieger B (2009) Mechanisms of $\mathrm{pH}$-gradient driven transport mediated by organic anion polypeptide transporters. Am J Physiol Cell Physiol 296:C570-82 DOI 00436.2008 [pii] 10.1152/ajpcell.00436.2008

33. Li HB, Lam DM (1990) Localization of neuropeptide-immunoreactive neurons in the human retina. Brain Res 522:30-6 DOI 0006-8993(90)91573-Y [pii]

34. Magistretti PJ, Morrison JH (1988) Noradrenaline- and vasoactive intestinal peptidecontaining neuronal systems in neocortex: functional convergence with contrasting morphology. Neuroscience 24:367-78

35. Mai JK, Stephens PH, Hopf A, Cuello AC (1986) Substance P in the human brain. Neuroscience 17:709-39

36. Matsas R, Kenny AJ, Turner AJ (1984) The metabolism of neuropeptides. The hydrolysis of peptides, including enkephalins, tachykinins and their analogues, by endopeptidase-24.11. Biochem J 223:433-40

37. Matsas R, Kenny AJ, Turner AJ (1986) An immunohistochemical study of endopeptidase-24.11 ("enkephalinase") in the pig nervous system. Neuroscience 18:9911012 DOI 0306-4522(86)90113-2 [pii] 
38. Matsas R, Kenny J, Turner A (1985) Endopeptidase-24.11 'enkephalinase': its role in the central nervous system. Prog Clin Biol Res 180:273-7

39. Nguyen-Legros J, Versaux-Botteri C, Vigny A (1986) Early development of tyrosine hydroxylase-like and substance P-like immunoreactivity in the human fetal retina. Hum Neurobiol 5:115-20

40. Noe B, Hagenbuch B, Stieger B, Meier PJ (1997) Isolation of a multispecific organic anion and cardiac glycoside transporter from rat brain. Proc Natl Acad Sci U S A $94: 10346-50$

41. Pinna G, Agis-Balboa RC, Pibiri F, Nelson M, Guidotti A, Costa E (2008) Neurosteroid biosynthesis regulates sexually dimorphic fear and aggressive behavior in mice. Neurochem Res 33:1990-2007 DOI 10.1007/s11064-008-9718-5

42. Pinna G, Rasmusson AM (2012) Upregulation of neurosteroid biosynthesis as a pharmacological strategy to improve behavioral deficits in a putative mouse model of PTSD. J Neuroendocrinol 24:102-16 DOI 10.1111/j.1365-2826.2011.02234.X

43. Pourcho RG (1996) Neurotransmitters in the retina. Curr Eye Res 15:797-803 DOI

44. Reichel C, Gao B, Van Montfoort J, Cattori V, Rahner C, Hagenbuch B, Stieger B, Kamisako T, Meier PJ (1999) Localization and function of the organic anion-transporting polypeptide Oatp2 in rat liver. Gastroenterology 117:688-95

45. Reye P, Penfold P, Pow DV (2001) Glyt-1 expression in cultured human Muller cells and intact retinae. Glia 34:311-5 DOI 10.1002/glia.1064 [pii]

46. Rupprecht R, Holsboer F (1999) Neuroactive steroids: mechanisms of action and neuropsychopharmacological perspectives. Trends Neurosci 22:410-6 DOI S01662236(99)01399-5 [pii] 
47. Said SI (1986) Vasoactive intestinal peptide. J Endocrinol Invest 9:191-200

48. St Pierre MV, Hagenbuch B, Ugele B, Meier PJ, Stallmach T (2002) Characterization of an organic anion-transporting polypeptide (OATP-B) in human placenta. J Clin Endocrinol Metab 87:1856-63

49. Straznicky C, Hiscock J (1989) Neuropeptide Y-like immunoreactivity in neurons of the human retina. Vision Res 29:1041-8

50. Strittmatter SM, Braas KM, Snyder SH (1989) Localization of angiotensin converting enzyme in the ciliary epithelium of the rat eye. Invest Ophthalmol Vis Sci 30:2209-14

51. Strittmatter SM, Lo MM, Javitch JA, Snyder SH (1984) Autoradiographic visualization of angiotensin-converting enzyme in rat brain with $[3 \mathrm{H}]$ captopril: localization to a striatonigral pathway. Proc Natl Acad Sci U S A 81:1599-603

52. Sullivan R, Rauen T, Fischer F, Wiessner M, Grewer C, Bicho A, Pow DV (2004) Cloning, transport properties, and differential localization of two splice variants of GLT1 in the rat CNS: implications for CNS glutamate homeostasis. Glia 45:155-69 DOI 10.1002/glia.10317

53. Suter M, Reme C, Grimm C, Wenzel A, Jaattela M, Esser P, Kociok N, Leist M, Richter C (2000) Age-related macular degeneration. The lipofusion component N-retinylN-retinylidene ethanolamine detaches proapoptotic proteins from mitochondria and induces apoptosis in mammalian retinal pigment epithelial cells. J Biol Chem 275:3962530 DOI 10.1074/jbc.M007049200b 007049200 [pii]

54. Tornqvist K, Ehinger B (1988) Peptide immunoreactive neurons in the human retina. Invest Ophthalmol Vis Sci 29:680-6 
55. Turner AJ, Tanzawa K (1997) Mammalian membrane metallopeptidases: NEP, ECE, KELL, and PEX. Faseb J 11:355-64

56. van de Steeg E, Wagenaar E, van der Kruijssen CM, Burggraaff JE, de Waart DR, Elferink RP, Kenworthy KE, Schinkel AH (2010) Organic anion transporting polypeptide 1a/1b-knockout mice provide insights into hepatic handling of bilirubin, bile acids, and drugs. J Clin Invest 120:2942-52 DOI 42168 [pii] 10.1172/JCI42168

57. Wheeler-Schilling TH, Sautter M, Guenther E, Kohler K (2001) Expression of angiotensin-converting enzyme (ACE) in the developing chicken retina. Exp Eye Res 72:173-82 DOI 10.1006/exer.2000.0944 S0014-4835(00)90944-8 [pii]

58. Wu KH, Madigan MC, Billson FA, Penfold PL (2003) Differential expression of GFAP in early v late AMD: a quantitative analysis. Br J Ophthalmol 87:1159-66

59. Zafra F, Aragon C, Olivares L, Danbolt NC, Gimenez C, Storm-Mathisen J (1995) Glycine transporters are differentially expressed among CNS cells. J Neurosci 15:395269

60. Zhang D, Yeh HH (1992) Substance-P-like immunoreactive amacrine cells in the adult and the developing rat retina. Brain Res Dev Brain Res 68:55-65 


\section{Figure Legends}

Fig. 1 Expression of OATP1A2 in human retina

A: Overview of immunolabelling at low magnification shows strong immunoreactivity for OATP1A2 in the outer nuclear layer (ONL), inner nuclear layer (INL) and ganglion cell layer (GCL) and weak labeling of the inner plexiform laer (IPL). B: Negative control with preabsorption of the antibody with the immunizing peptide displays some autofluorescence in the retina pigment epithelium (RPE). C: High magnification centered on the ONL show plasma membrane labeling of retina photoreceptor bodies. scale bar: $60 \mu \mathrm{M}$ D: Corresponding differential interference contrast (DIC) image to section C. scale bar: $12 \mu \mathrm{M}$ E: High magnification of the IPL demonstrates immunoreactivity of INL, IPL, and GCL. Note that stained amacrine cells (marked with an asterisk) extend their heavily labeled processes to the IPL and GCL. F: Corresponding DIC image to section E. scale bar: $10 \mu \mathrm{M}$

Fig. 2 Expression of OATP2B1 in human retina

A: Overview of immunolabelling at low magnification shows strong immunoreactivity for OATP2B1 in the inner part of INL and of IPL. For orientation, the choroid is labeled with Ch. B: Negative control with preabsorption of the antibody with the immunizing peptide displays some autofluorescence in the RPE. scale bar: $55 \mu \mathrm{M} \mathrm{C}$ : High magnification centered around INL with the corresponding DIC image (shown in D) shows immunolabeling of proximal processes of amacrine cells (marked with an 
asterisk) in INL and positive neuronal processes in a dense plexus in IPL. D: DIC image corresponding to section C. scale bar: $13 \mu \mathrm{M}$

Fig. 3 Verification of OATP1A2 and OATP2B1 expression on Western blots of human retina homogenates

Retina homogenates were prepared and processed for Western blotting as described in Materials and Methods. The blots were probed with OATP1A2 antibody (lane 1), OATP1A2 antibody preabsorbed with immunizing peptide (lane 2), OATP2B1 antibody (lane 3) and OATP2B1 antibody preabsorbed with immunizing peptide (lane 4).

Fig. 4 Uptake of substance $P$ and vasoactive intestinal peptide into OATP1A2and OATP2B1-expressing Xenopus laevis oocytes

OATPs were expressed in X. laevis oocytes and uptakes of either $0.2 \mu \mathrm{M}$ substance $\mathrm{P}(\mathrm{SP}), 2.5 \mathrm{nM}$ vasoactive intestinal peptide (VIP), $1.5 \mathrm{pM}$ somatostatin (SOM) or $47 \mathrm{nM}$ neuropeptide Y (NPY) were determined over $30 \mathrm{~min}$ as described in Materials and Methods. Values are given as means \pm SD uptakes determined in of 12 to 15 oocytes incubated in $100 \mathrm{mM} \mathrm{NaCl}$ or $100 \mathrm{mM}$ choline chloride containing medium. $* \mathrm{p}<0.5, * *$ $\mathrm{p}<0.01$

Fig. 5 Kinetics of OATP1A2- and OATP2B1-mediated uptake of substance P (SP) and vasoactive intestinal peptide (VIP) in X. laevis oocytes

OATPs were expressed in $X$. laevis oocytes and uptake of increasing concentrations of SP and VIP into X. laevis oocytes was determined over $30 \mathrm{~min}$ as described in Materials and Methods. Uptake values are given as the difference between 
OATP expressing oocytes and control (water injected) oocytes. Values are given as means $\pm \mathrm{SD}$ of uptakes into 12 to 15 oocytes incubated in $100 \mathrm{mM} \mathrm{NaCl}$ containing medium. The curves were fitted by nonlinear regression analysis (GraphPad Prism, San Diego CA) to the Michaelis-Menten equation.

Fig. 6 Colocalization of OATP1A1 and OATP2B1 and substance P (SP)

A: OATP1A2 immunofluorescence is depicted in red (left column) and SP immunofluorescence is in green (middle column). The right column shows an extensive colocalization (yellow) of OATP1A2 and its substrate SP in amacrine cells (marked with arrows) of INL and neurites (marked with arrows) of IPL and GCL. scale bar: $18 \mu \mathrm{M} \mathbf{B}$ : OATP2B1 immunofluorescence is coloured red (left column) and SP immunofluorescence is shown in green (middle column). The right column shows colocalization (yellow) of OATP2B1 and its substrate SP in neuronal processes (marked with arrows) of IPL. scale bar: $18 \mu \mathrm{M}$

Fig. 7 Colocalization of OATP1A2 and OATP2B1 and vasoactive intestinal peptide (VIP)

A: OATP1A2 immunofluorescence is shown in red (left column) and VIP immunofluorescence is in green (middle column). The right column shows an extensive colocalization (yellow) of the OATP1A2 and its VIP substrate in small cells and neurites in GCL and colocalization OATP1A2 and its substrate in IPL and INL. scale bar: $10 \mu \mathrm{M}$ B: OATP2B1 immunofluorescence is given in red (left column) and SP immunofluorescence is in green (middle column). The right column shows colocalization (yellow) of OATP2B1 and its substrate VIP in neuronal processes in INL and IPL. scale bar: $13 \mu \mathrm{M}$ (upper), $13 \mu \mathrm{M}$ (bottom) 
Fig. 8 Immunolocalization of OATP1A2 in human frontal cortex

A: Overview of OATP1A2 immunolabelling showing scattered imunoreactivity in various layers. scale bar: $400 \mu \mathrm{M}$ B: OATP1A2 immunoreactivity is absent in the negative control after preabsorption of the antibody with the immunizing peptide. $\mathbf{C}$ : Higher magnification demonstrating a clear OATP1A2 labeling in cell somas and neuronal processes. scale bar: $43 \mu \mathrm{M}$

Fig. 9 Immunolocalization of OATP1A2 in human hippocampal formation

A: Composite of sections across hippocampal areas showing an overview of OATP1A2 immunolabelling with intense labelling from CA1 to CA3. scale bar: $700 \mu \mathrm{M}$ B: The close-up of the CA-2 region shows OATP1A2 immunopositivity in numerous pyramidal neurons and their processes. C: OATP1A2 immunoreactivity is predominantly present in the plasma membrane of granule cell somas and neuronal processes in the stratum moleculare of the dentate gyrus (SM). scale bar: $37 \mu \mathrm{M}$

Fig. 10 Immunolocalization of OATP2B1 in human frontal cortex and in hippocampus

A: OATP2B1 immunoreactivity in brain capillaries of human frontal cortex (negative control in insert). scale bar: $15 \mu \mathrm{M} \mathrm{B}$ : OATP2B1 immunoreactivity in brain capillaries of human hippocampus. scale bar: $150 \mu \mathrm{M}$ C: A close-up of B confirming the exclusive expression of OATP2B1 in the capillary endothelium. scale bar: $43 \mu \mathrm{M}$ 


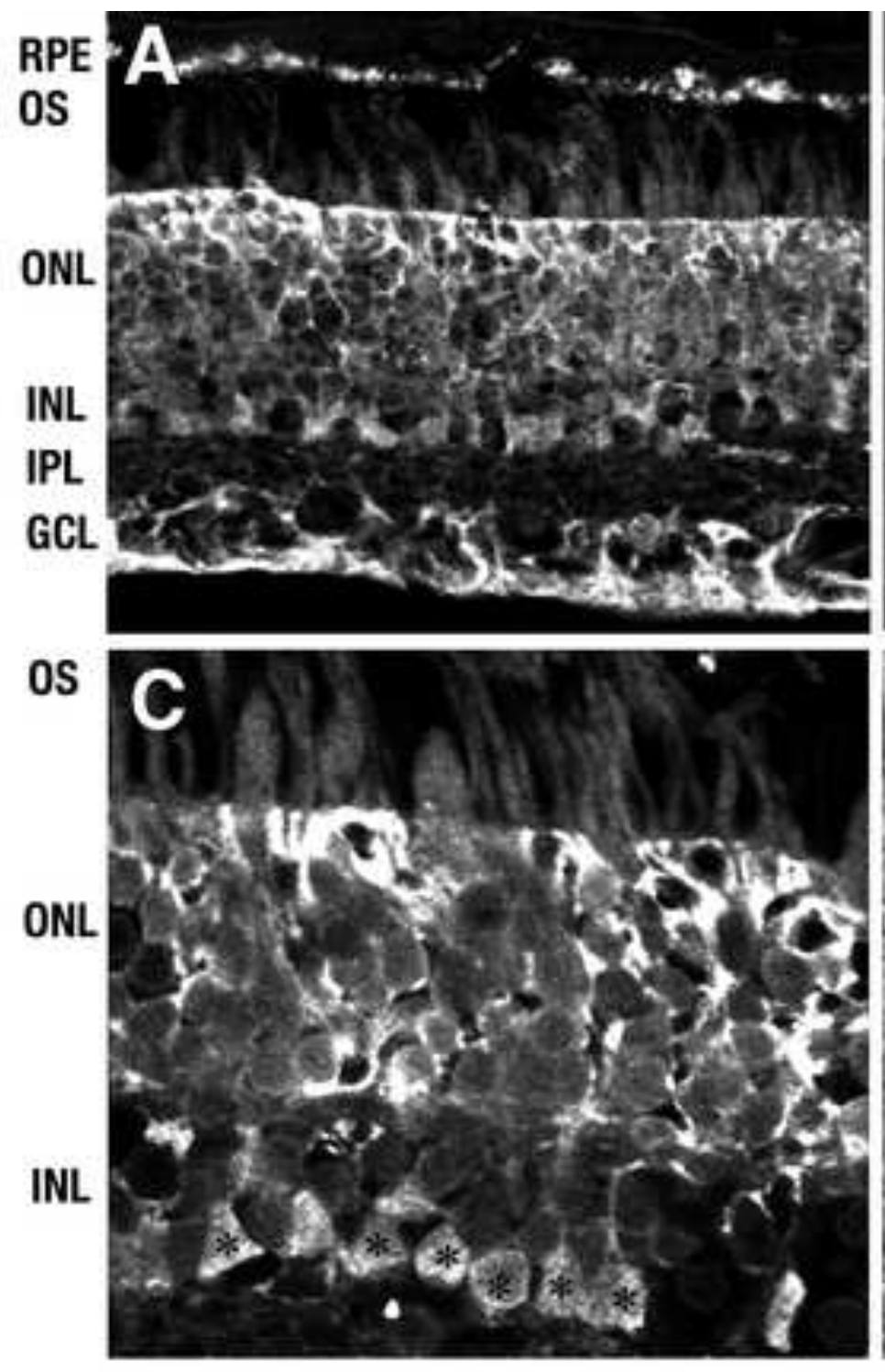

\section{B}

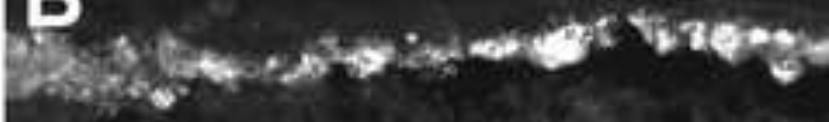

ONL

mis
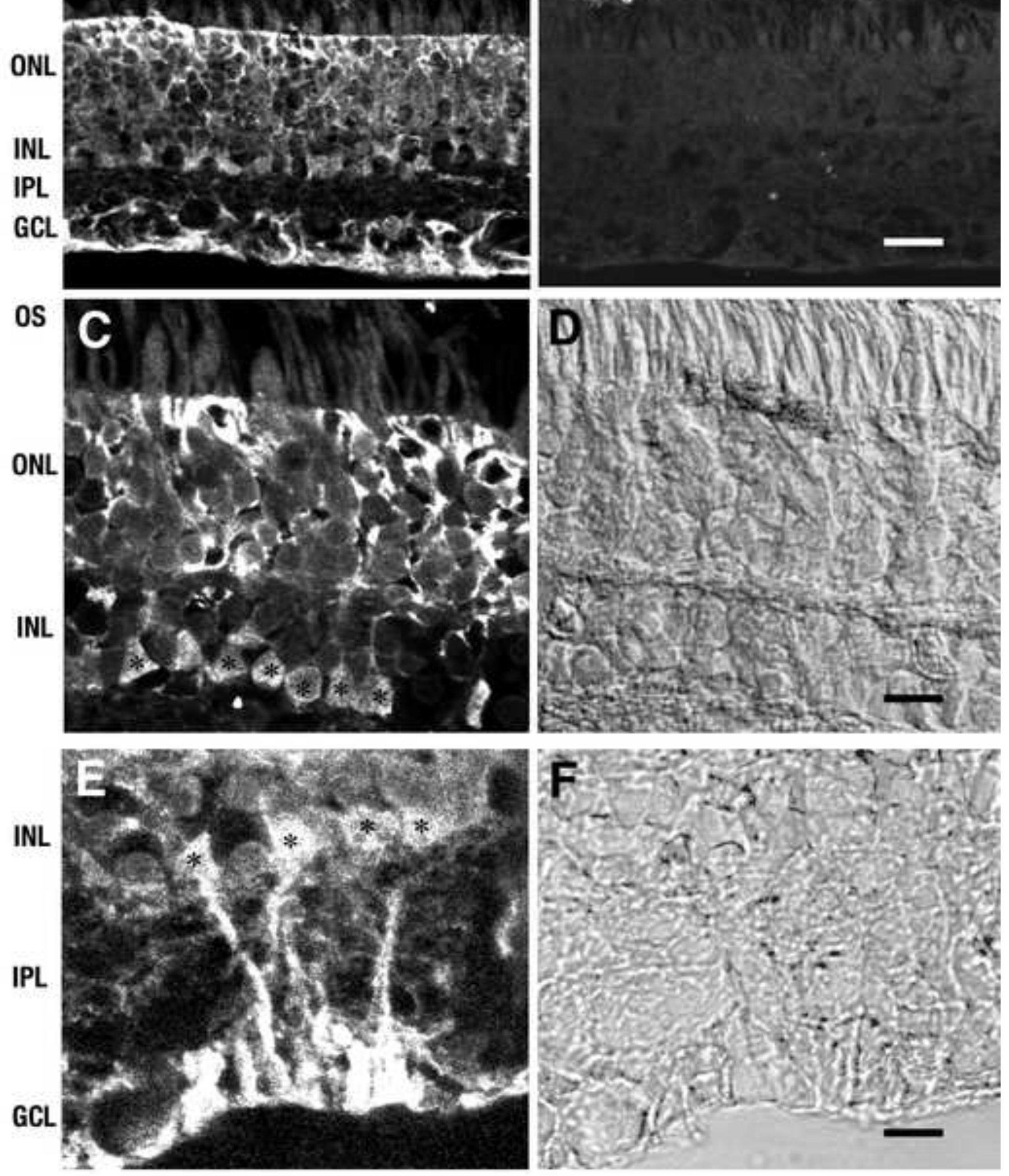


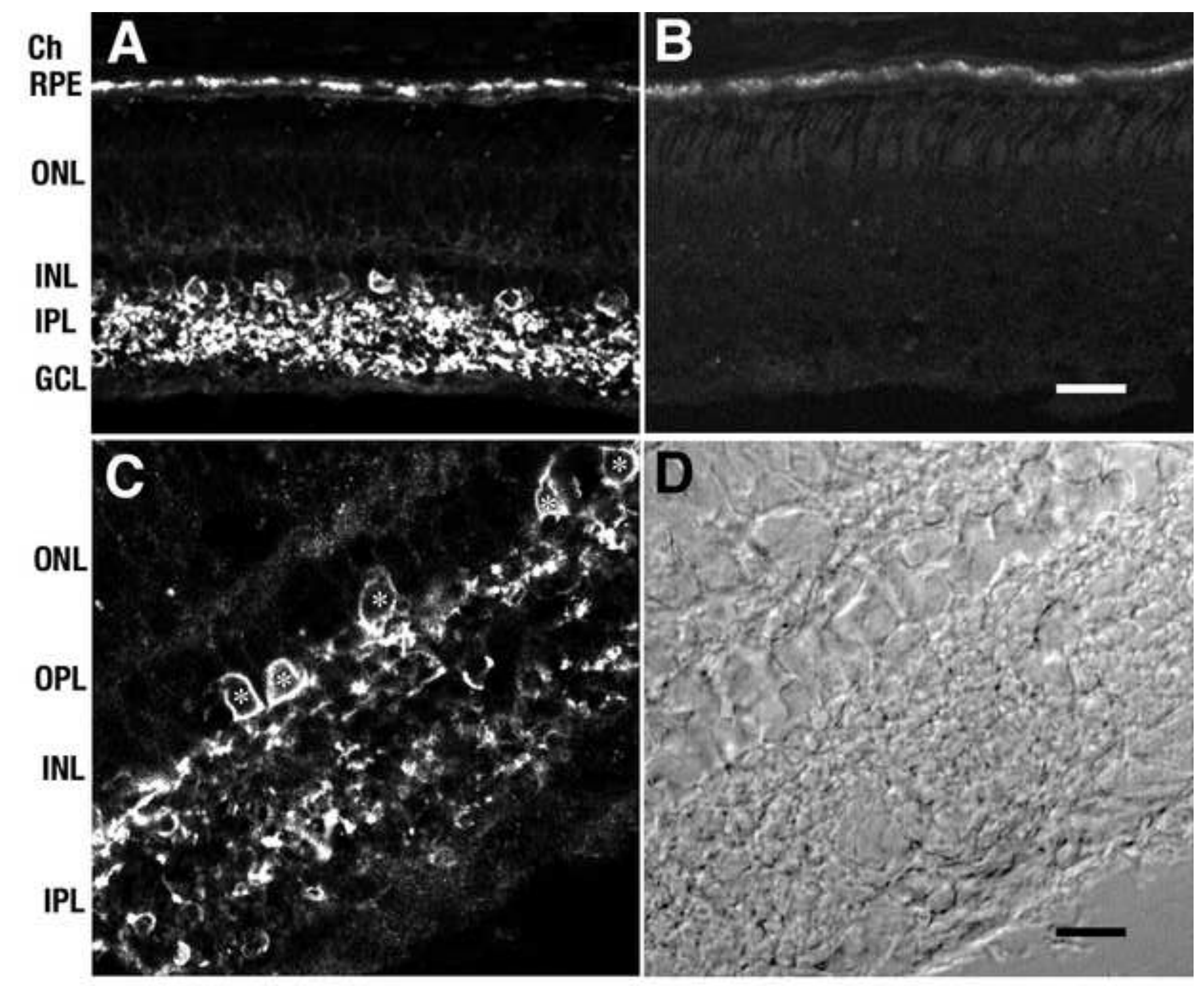


Fig. 3

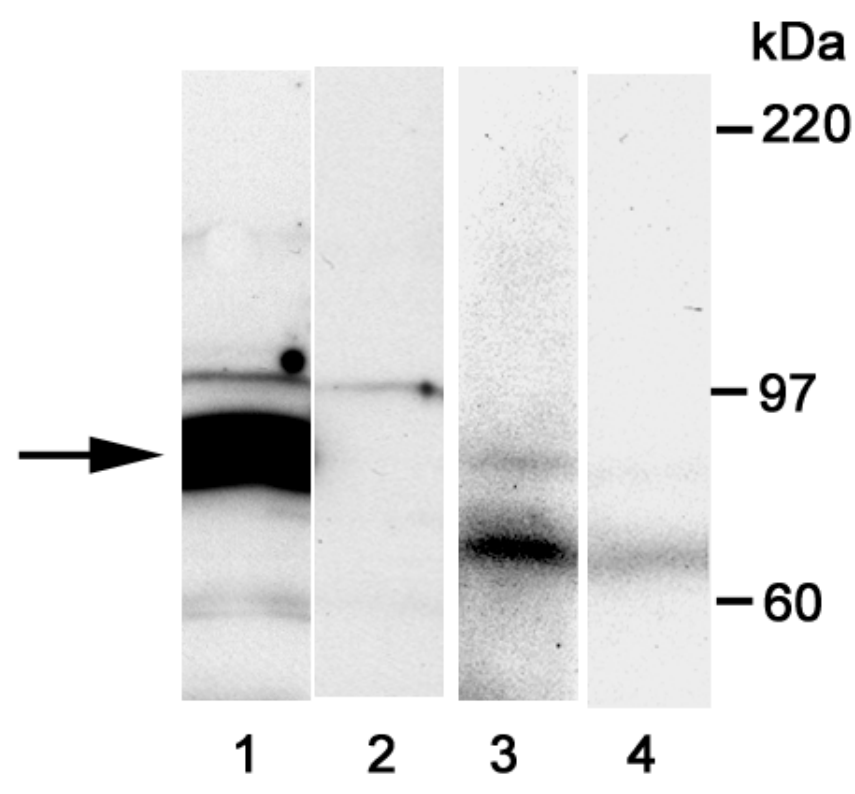


Fig. 4
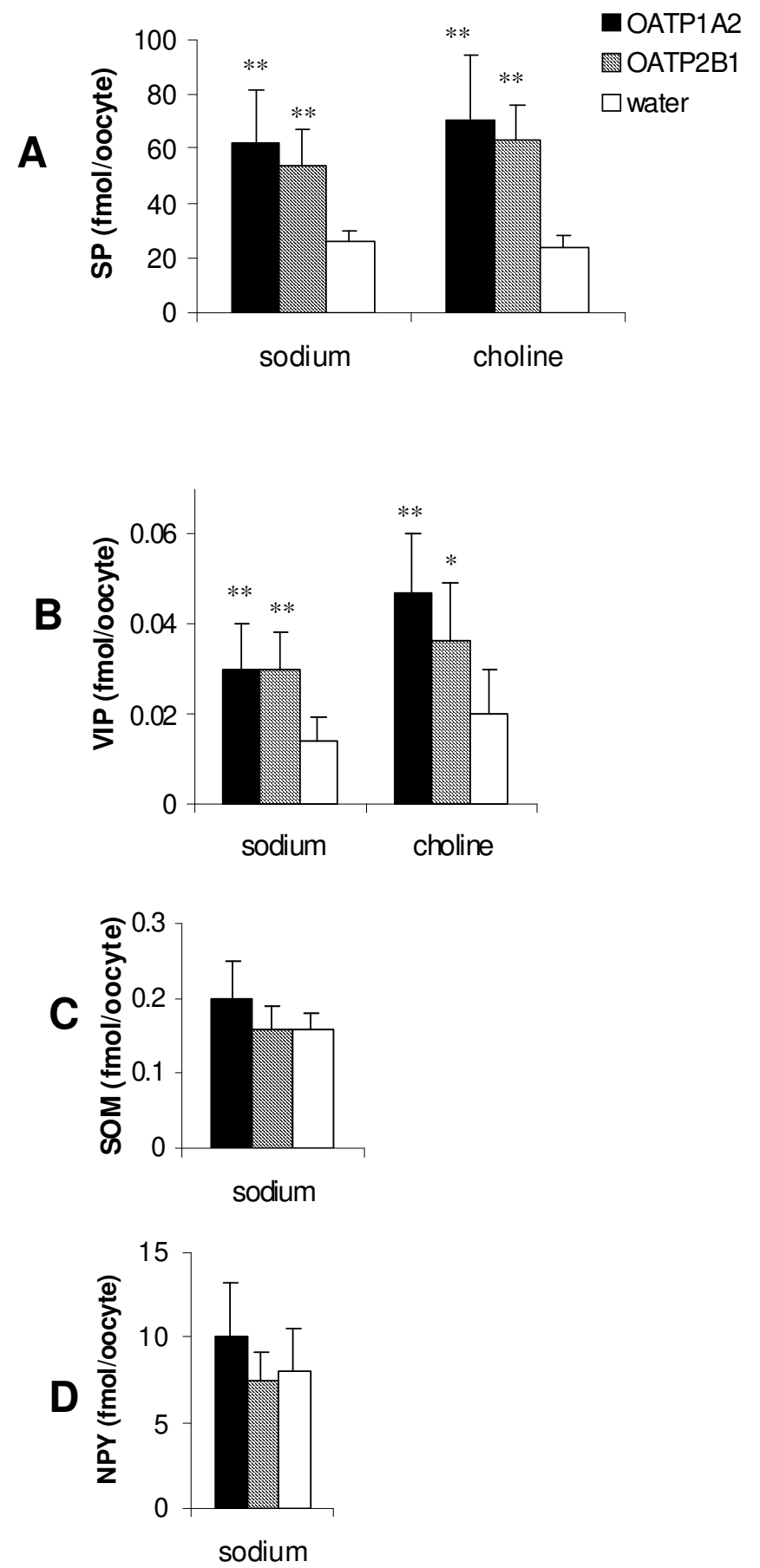
Fig. 5
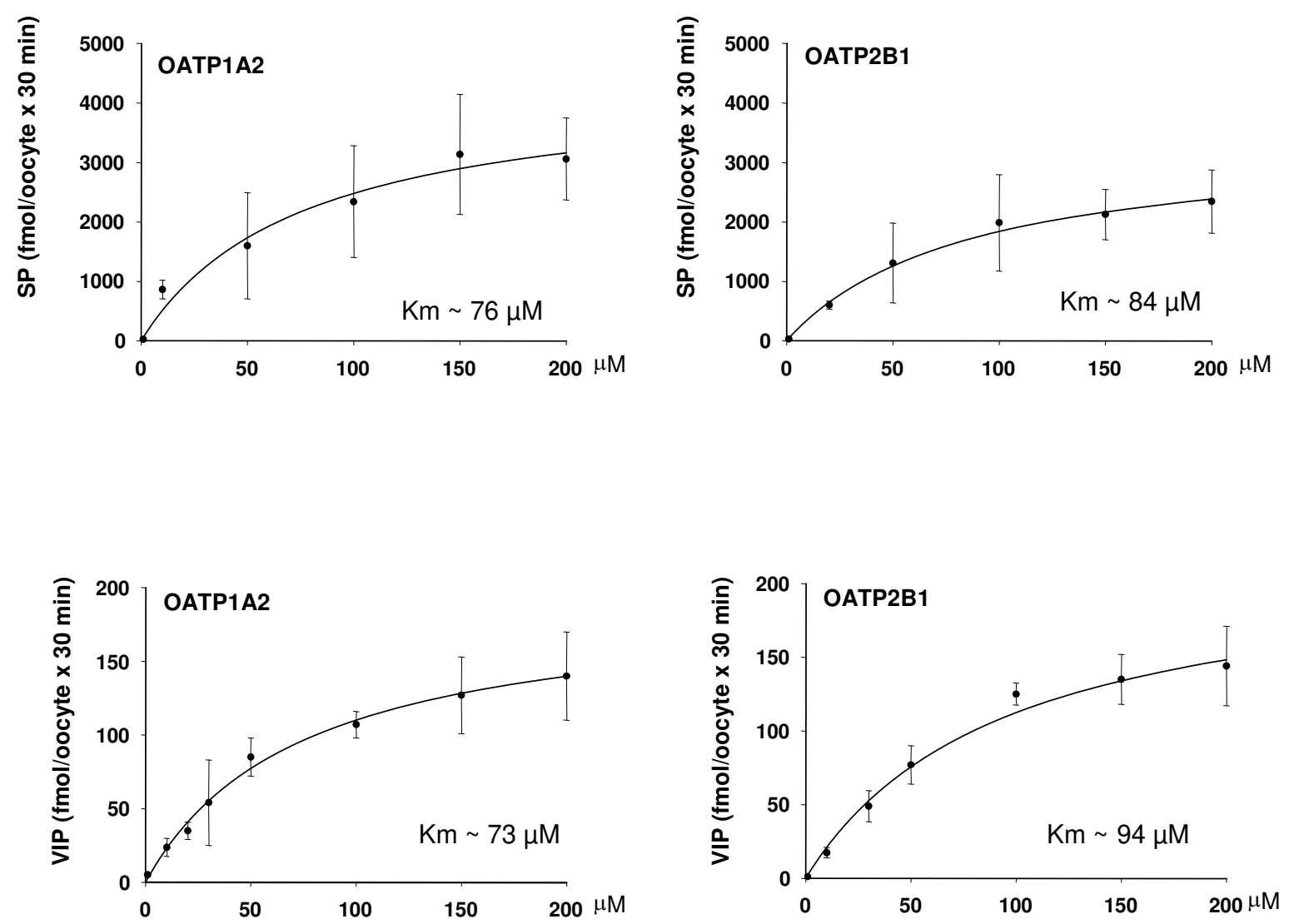
A
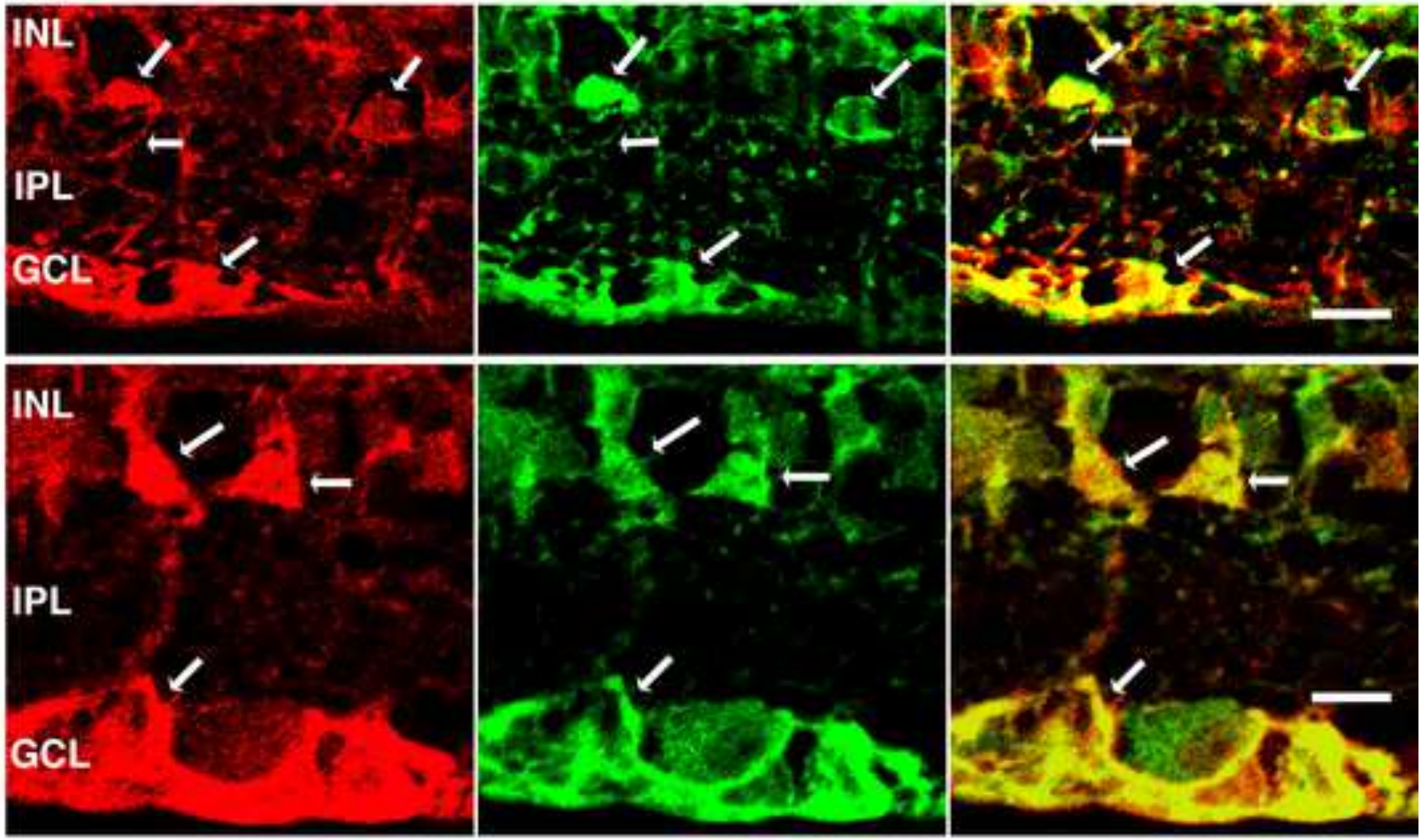

\section{B}
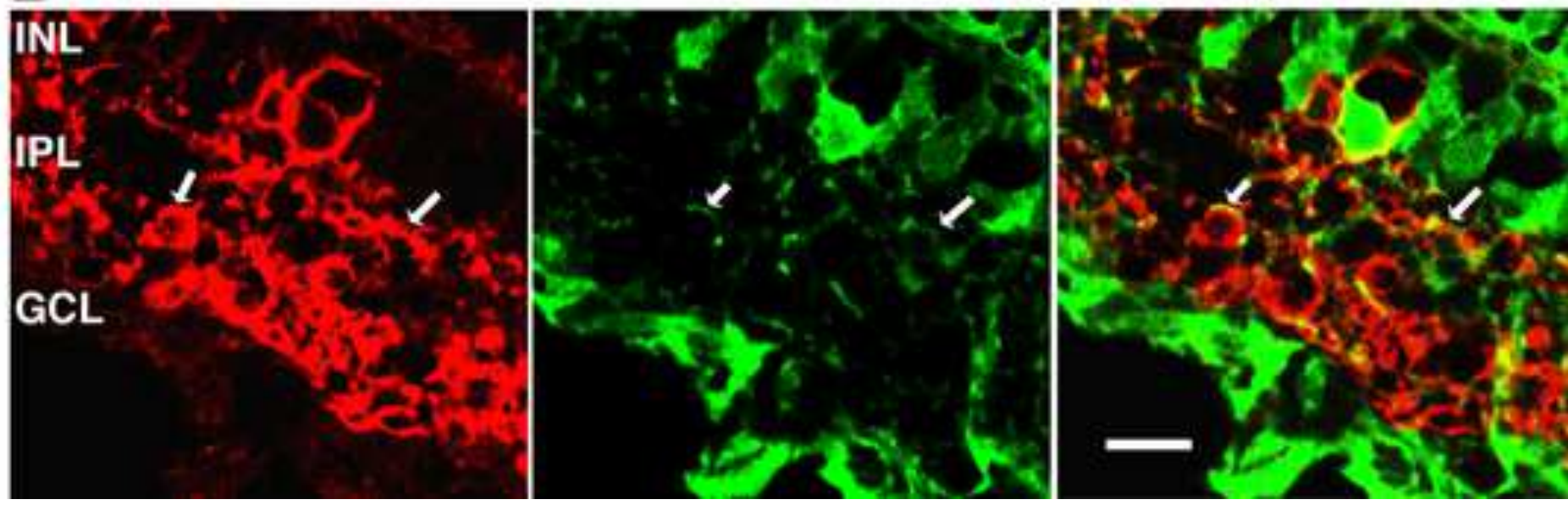


\section{Figure 7}

Click here to download high resolution image

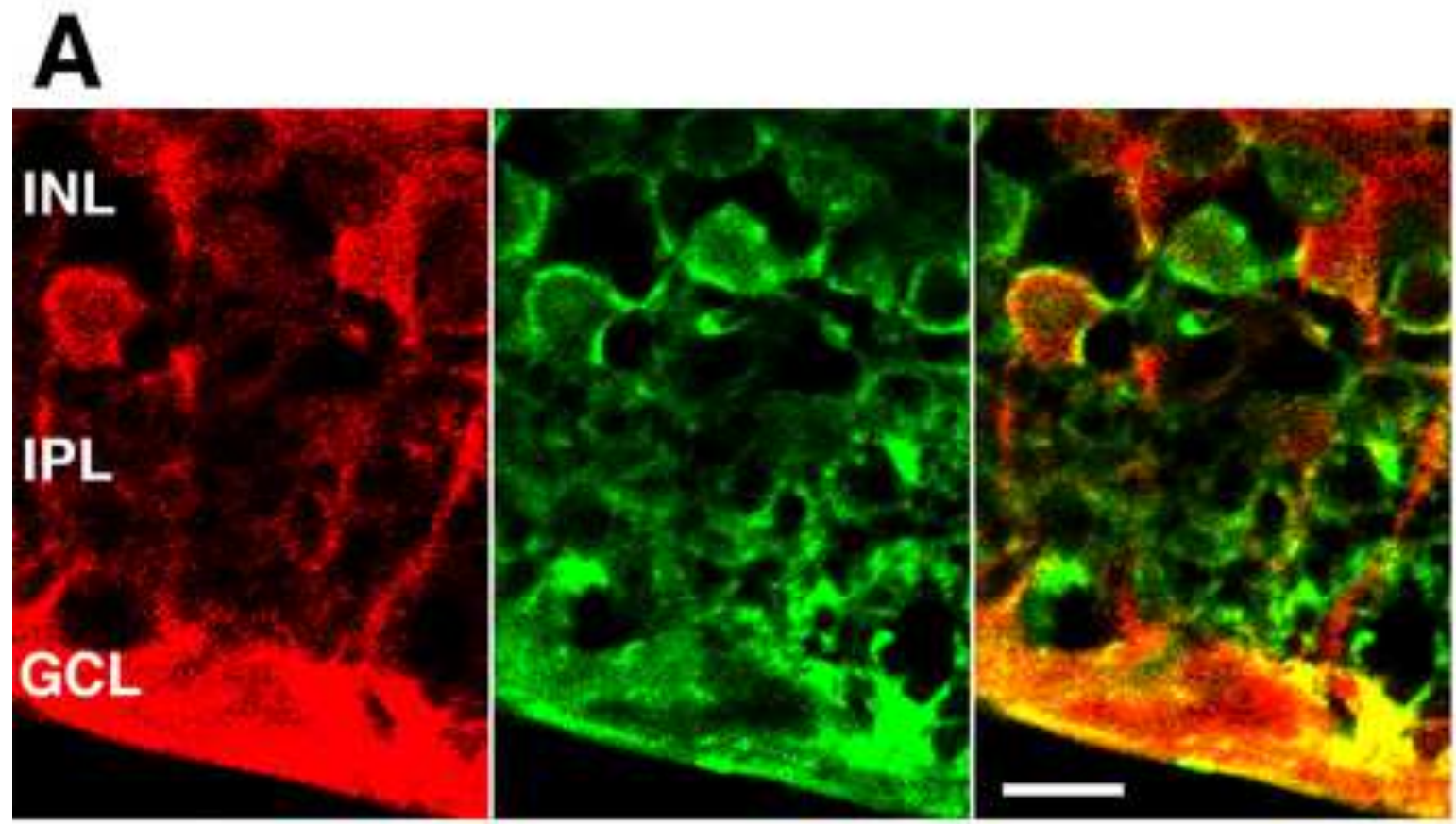

\section{B}

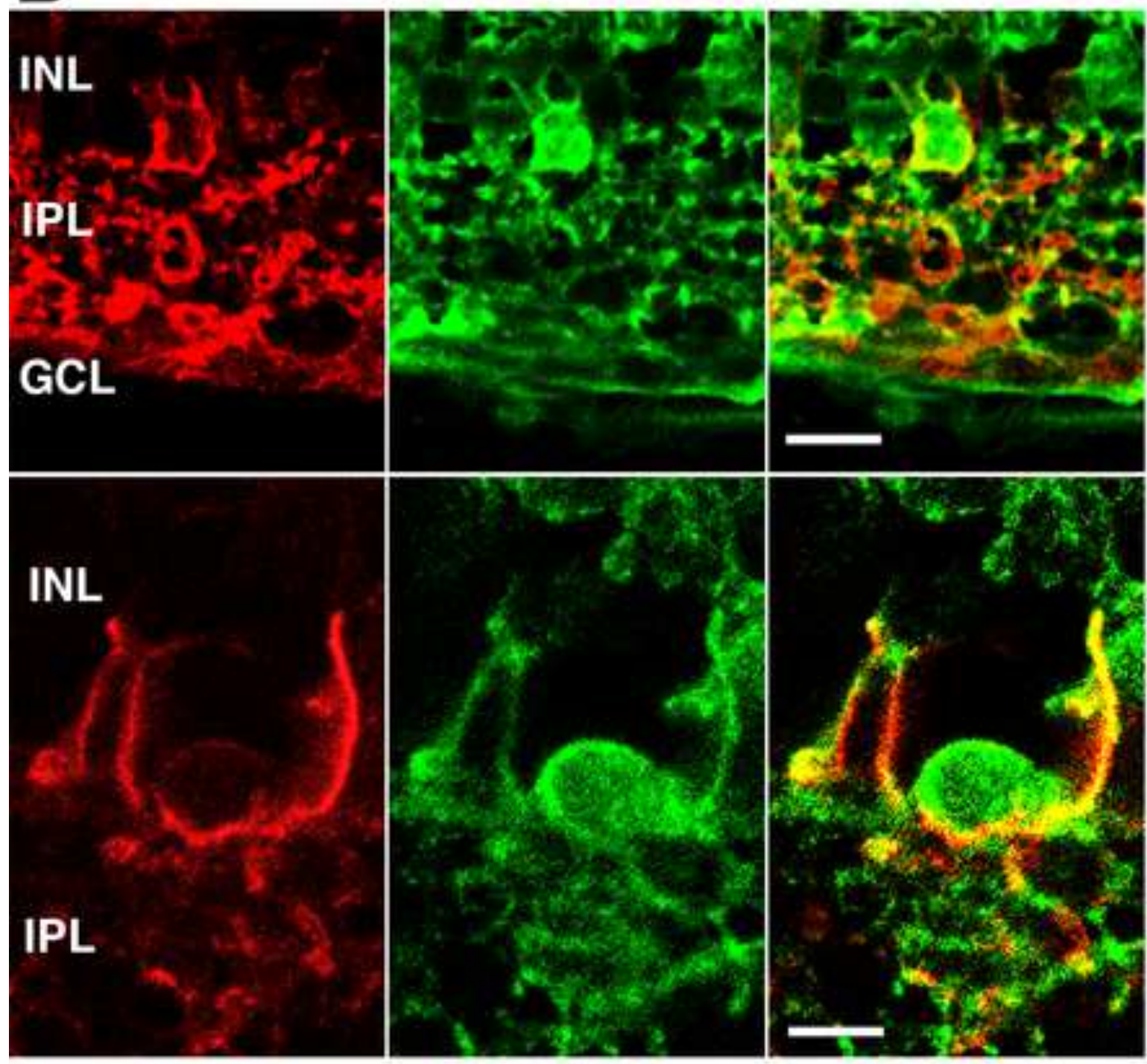




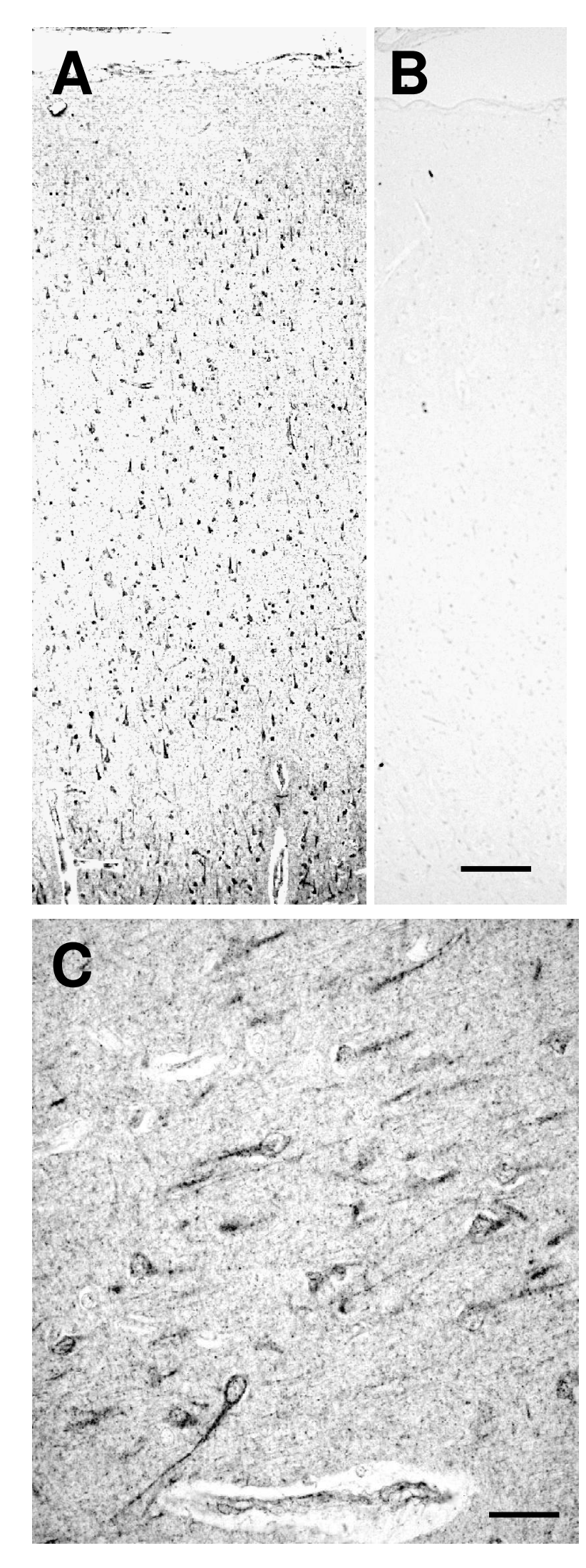

Figure 8

\section{Fig. 8}

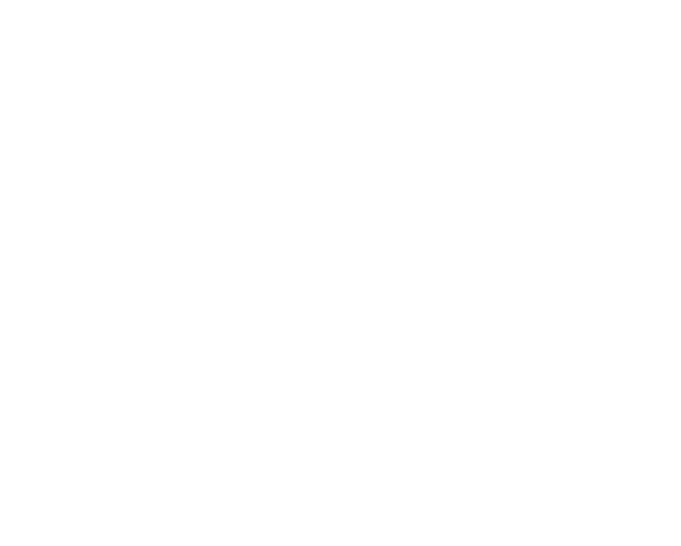


Fig. 9
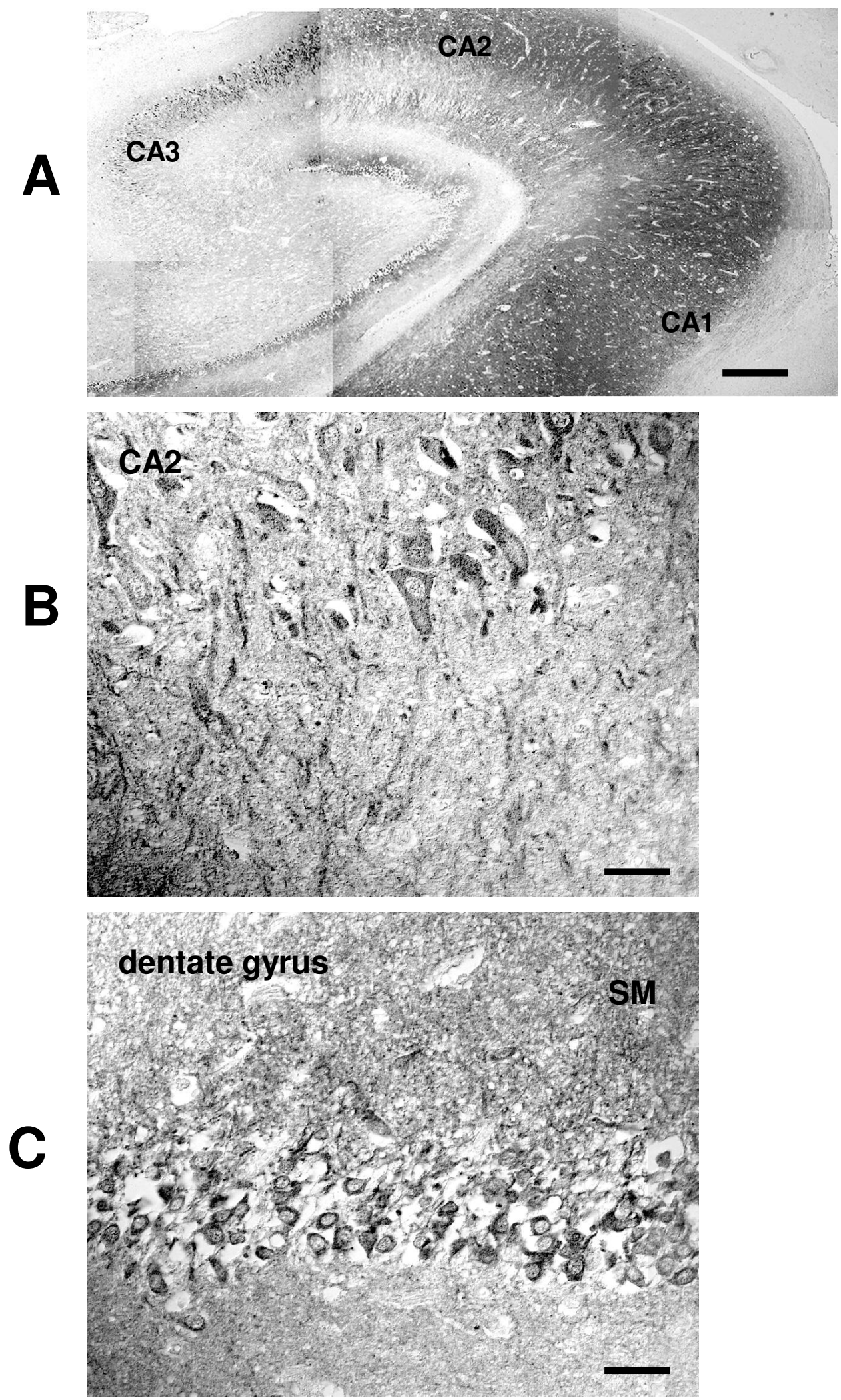

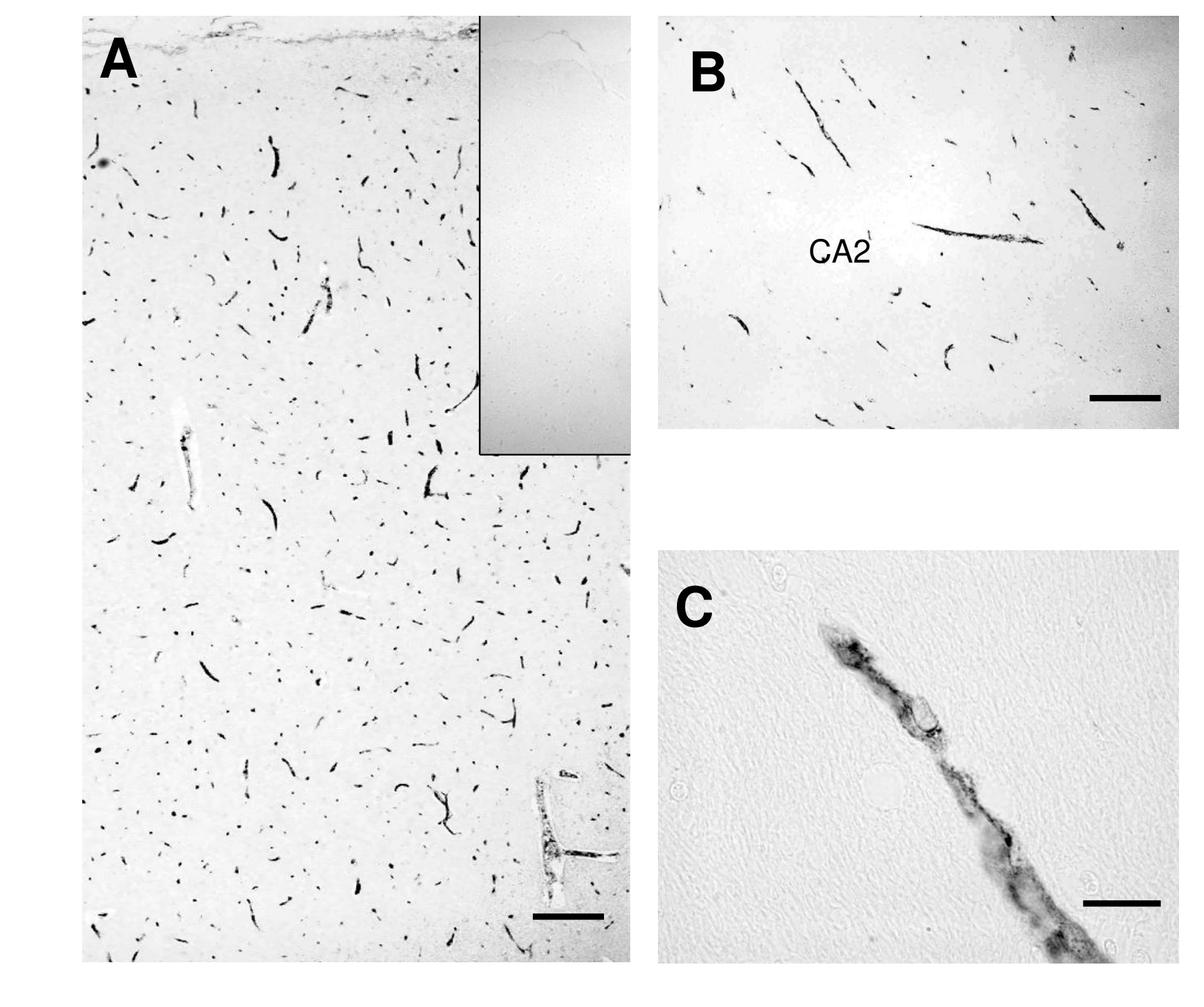

\section{Fig. 10}

(1)
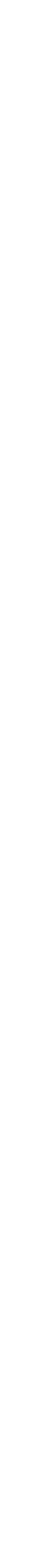